\title{
Optimisation of gold recovery from small scale custom mills
}

\author{
Willie Nheta, Mahlori Nkwinika, Moselyn Mailula \\ University of Johannesburg \\ Mineral Processing and Technology Research centre \\ P.O.BOX 17011, Doornfontein 2028, Johannesburg, South Africa \\ wnheta@uj.ac.za; mahlori1999@gmail.com;
}

\begin{abstract}
Custom mill tailings generated during the treatment of gold ores in Custom milling plants contains a considerable significant amount of gold $\mathrm{(Au}$ ) and Silver $(\mathrm{Ag})$. The potential of recovering gold and silver from the tailings by cyanidation leaching process was investigated. The custom mill tailings were characterised using Malvern particle analyser, XRF, XRD and SEM-EDs. In this study, the MiniTab software experimental design method was used to determine the optimum leaching conditions. The PSD results revealed that the custom mill tailings are coarse with $80 \%$ passing $2000 \mu \mathrm{m}$. The tailings are a quartzite material containing minor amount of sulphides such as pyrite, chalcopyrite and pentlandite. The amount of these sulphides is very low ruling the probability of the tailings being refractory. Recoveries of 88 and $95 \%$ for gold and silver respectively were achieved leaching at $800 \mathrm{~g} / \mathrm{t}$ $\mathrm{NaCN} 8 \mathrm{hrs}$. However, gold recovery above $85 \%$ was achieved by leaching in $600 \mathrm{~g} / \mathrm{t} \mathrm{NaCN}$ for $8 \mathrm{hrs}$. Custom mill tailings have proved to be a source of precious metals and Min Tab software is a useful tool in optimisation of the leaching conditions.
\end{abstract}

Keywords: Gold, small scale mining, artisanal mining, gold leaching, tailings.

\section{Introduction}

Gold small scale mining (SSM) and artisanal small scale gold mining (ASGM) was treated as illegal mining in many countries for a long time [1]. This led to poor technology development in this area and till today many small scale miners use rudimental equipment. Some countries such as Mozambique, Ghana, Burkina Faso and Zimbabwe has legalised this sector and it is contributing immensely to their total gold production per year. Most of the methods used in SSM/ ASGM mining are gravity concentration methods followed by amalgamation. Amalgamation has been condemned in many countries due to mercury pollution but it has remained the primary method of gold extraction in many developing countries. This is due to the fact that amalgamation is inexpensive but inefficient [2]. This has led to development of extraction methods such as the mercury free small scale gold extraction method $[3,4]$. This method involves smelting of gold using borax instead of mercury and about $78 \%$ more gold recovery has been claimed [4].

Although the main problem with small scale gold miners is mercury pollution, use of women and child labour, poor recoveries and insufficient knowledge amongst the miners are also major problems [5]. The poor recoveries occur due to inefficient processes that are used prior to the amalgamation or mercury free smelting process. These inefficiencies include poor liberation of the gold particles from the gangue. Generally, hummer mills and wet pans are used for the comminution of the ore prior to gravity concentration process and these produce a coarse product. Though gravity concentration process works well with a course fraction, gold recoveries are usually around 50\%. Hence, most of the gold is lost to the tailings. As a results, some of the small scale miners in Mozambique and Zimbabwe have modified the processing circuit by adding leaching processes to the gravity concentration tailings. Still, recoveries in this section are still low due to poor liberation, short residence time, poor aeration and use of incorrect concentrations of sodium cyanide and caustic soda. Apart from that, there is poor understanding of the nature of the gold ores. Some ores are refractory and they need pre-treatment prior to leaching $[6,7]$.

In this study, characterisation of gold custom mill tailings obtained from one of the ASGM operation was done. The effect of cyanide concentration and leaching time on the gold recovery were investigated and optimised using Mini tab software with the main aim of recovering gold lost to the tailings during gold custom mill operations. Other gold leaching parameters were kept constant. 


\section{Methodology}

\subsection{Materials}

The gold sample used in the investigation was sourced from one of the ASGM projects in Shamva, Zimbabwe. The tailings from the gold custom mill contained $2.01 \mathrm{~g} / \mathrm{t}$ Au and $1.5 \mathrm{~g} / \mathrm{t} \mathrm{Ag}$. The sample was milled

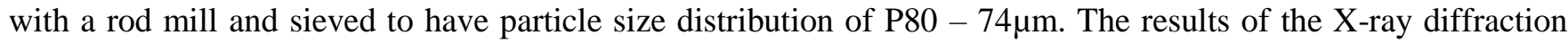
(XRD) of the sample are shown in Figure 1 and the chemical composition obtained using X-ray fluorescence (XRF) is shown in Table 1. Sodium cyanide at $98 \%$ purity and Calcium hydroxide at $95 \%$ was used for the leaching experiments.

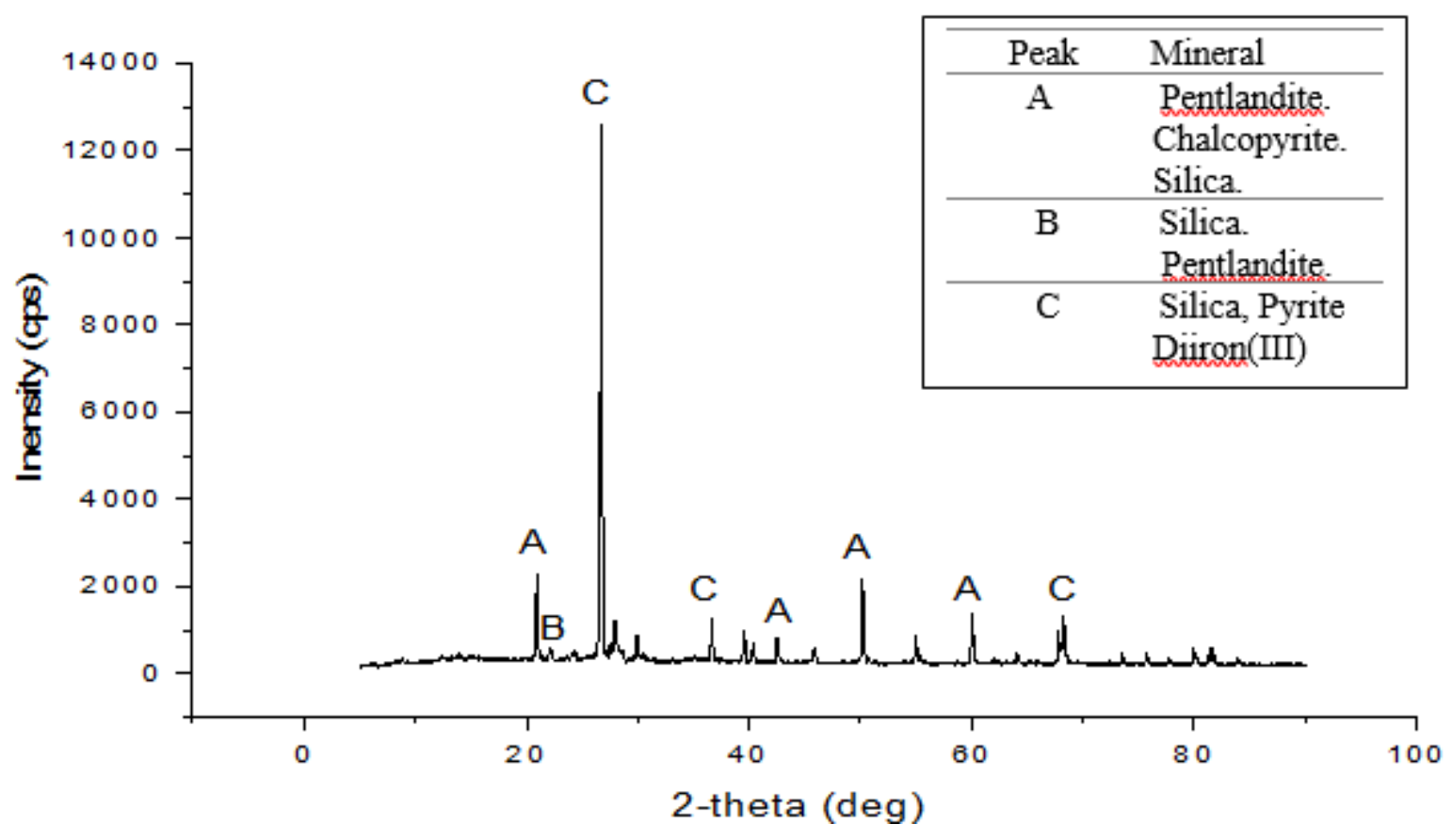

Fig 1: Mineral phases of the of the custom mill gold tailings.

Table 1: Elemental analyses of the custom mill gold tailings.

\begin{tabular}{|l|l|l|l|l|l|l|l|l|l|l|l|l|}
\hline Element & $\mathrm{Na}$ & $\mathrm{Mg}$ & $\mathrm{Al}$ & $\mathrm{Si}$ & $\mathrm{P}$ & $\mathrm{S}$ & $\mathrm{Cl}$ & $\mathrm{K}$ & $\mathrm{Ca}$ & $\mathrm{Ti}$ & $\mathrm{V}$ & $\mathrm{Cr}$ \\
\hline \%wt. & 1.4 & 1.3 & 9.7 & 62.4 & 0.1 & 0.3 & 0.1 & 3.6 & 3.9 & 0.9 & 0.04 & 0.1 \\
\hline Element & $\mathrm{Mn}$ & $\mathrm{Fe}$ & $\mathrm{Ni}$ & $\mathrm{Cu}$ & $\mathrm{Zn}$ & $\mathrm{As}$ & $\mathrm{Rb}$ & $\mathrm{Sr}$ & $\mathrm{Zr}$ & $\mathrm{Ba}$ & $\mathrm{Au}$ & $\mathrm{Pb}$ \\
\hline \%wt. & 0.2 & 15 & 0.04 & 0.07 & 0.08 & 0.33 & 0.02 & 0.1 & 0.03 & 0.11 & 0.008 & 0.33 \\
\hline
\end{tabular}

\subsection{Leaching experiments}

Minitab software was used for the design of experiments focusing on the effect of $\mathrm{NaCN}$ concentration and leaching time on gold recovery [8]. The full factorial design matrix for the leaching experiments is shown in Table 1. 
Table 2: Full factorial design matrix for the gold leaching experiments.

\begin{tabular}{|c|c|c|}
\hline Leaching experiment & Time (hours) & $\begin{array}{c}\text { NaCN dosage } \\
(\mathrm{ppm})\end{array}$ \\
\hline 1 & 3 & 150 \\
\hline 2 & 3 & 210 \\
\hline 3 & 3 & 500 \\
\hline 4 & 6 & 150 \\
\hline 5 & 6 & 210 \\
\hline 6 & 12 & 500 \\
\hline 7 & 12 & 150 \\
\hline 8 & 12 & 500 \\
\hline 9 & & \\
\hline
\end{tabular}

A 500g tailings sample with a PSD of $80 \%$ passing 74 microns was mixed with water to form a slurry with $50 \%$ solids. The $\mathrm{pH}$ of the slurry was adjusted to a $\mathrm{pH}$ of 11 using Calcium hydroxide and conditioned for ten minutes. $\mathrm{NaCN}$ was then added according to conditions shown in Table 1. The leaching experiments were carried out in a water bath as shown in Figure 3 at different leaching time according to Table 1.

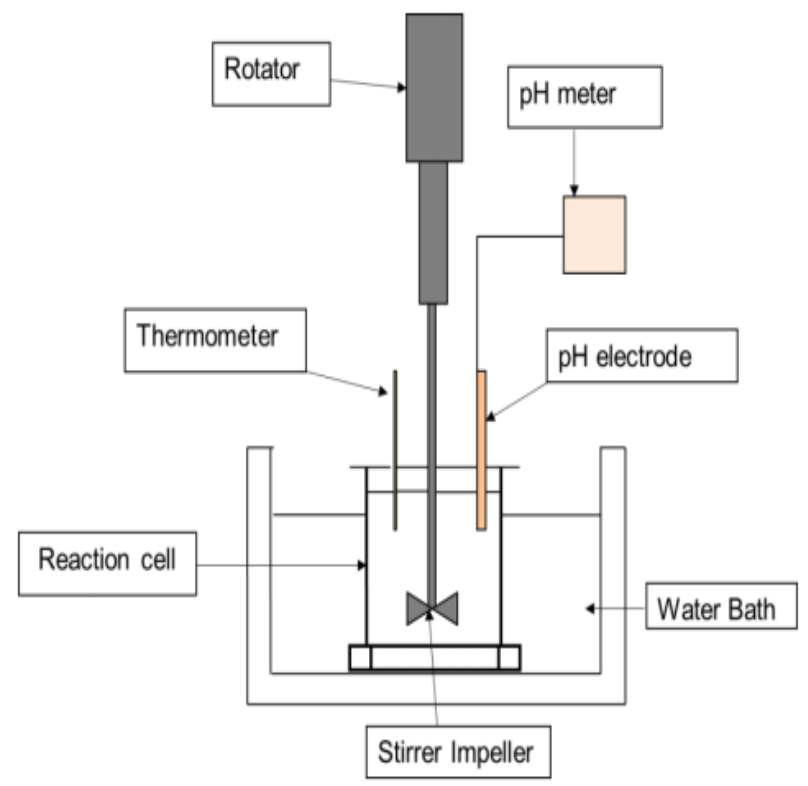

Fig 2: Schematic diagram of equipment set-up for the gold leaching process. 
For all the leaching tests the values of the parameters that were kept constant are shown in Table 4.

Table 3: Values of the constant parameters for all the leaching experiments

\begin{tabular}{|l|l|}
\hline Parameter & Value \\
\hline Temperature & $25^{\circ} \mathrm{C}$ \\
\hline $\mathrm{pH}$ & 11 \\
\hline Stirring rate & $900-1000 \mathrm{rpm}$ \\
\hline \% solids & $50 \%$ \\
\hline $\begin{array}{l}\text { Mass of gold } \\
\text { sample }\end{array}$ & $500 \mathrm{~g}$ \\
\hline $\begin{array}{l}\text { Conditioning } \\
\text { time before } \\
\text { each test }\end{array}$ & $10 \mathrm{mins}$ \\
\hline D & 74 microns \\
\hline
\end{tabular}

\subsection{Analytical Method}

The elemental composition of the samples were identified using a Rigaku ZSX Primus II -X-Ray Fluorescence (XRF) machine. The mineralogical phases were identified using the Rigaku Ultima X-ray diffraction (XRD) with $\mathrm{Cu}$ K $\alpha$ radiation. Gold and silver concentration in the solids residue and the head sample were measured using fire assaying and finished by ICP analyses. The morphology of the chromite ore in the samples was analysed using TESCA scanning electron microscope (SEM).

\section{Results and Discussion}

\subsection{Sample characterisation}

The particle size distribution of the custom mill tailings was studied using a Malvern particle analyser and the results are shown in Figure 3. Shows that $80 \%$ of the material is passing 2000 microns. This shows that the material is still coarse and requires further grinding because the cyanidation method is only applicable for ores, concentrates and tailings having a particle size range less than 200 microns [8]. 


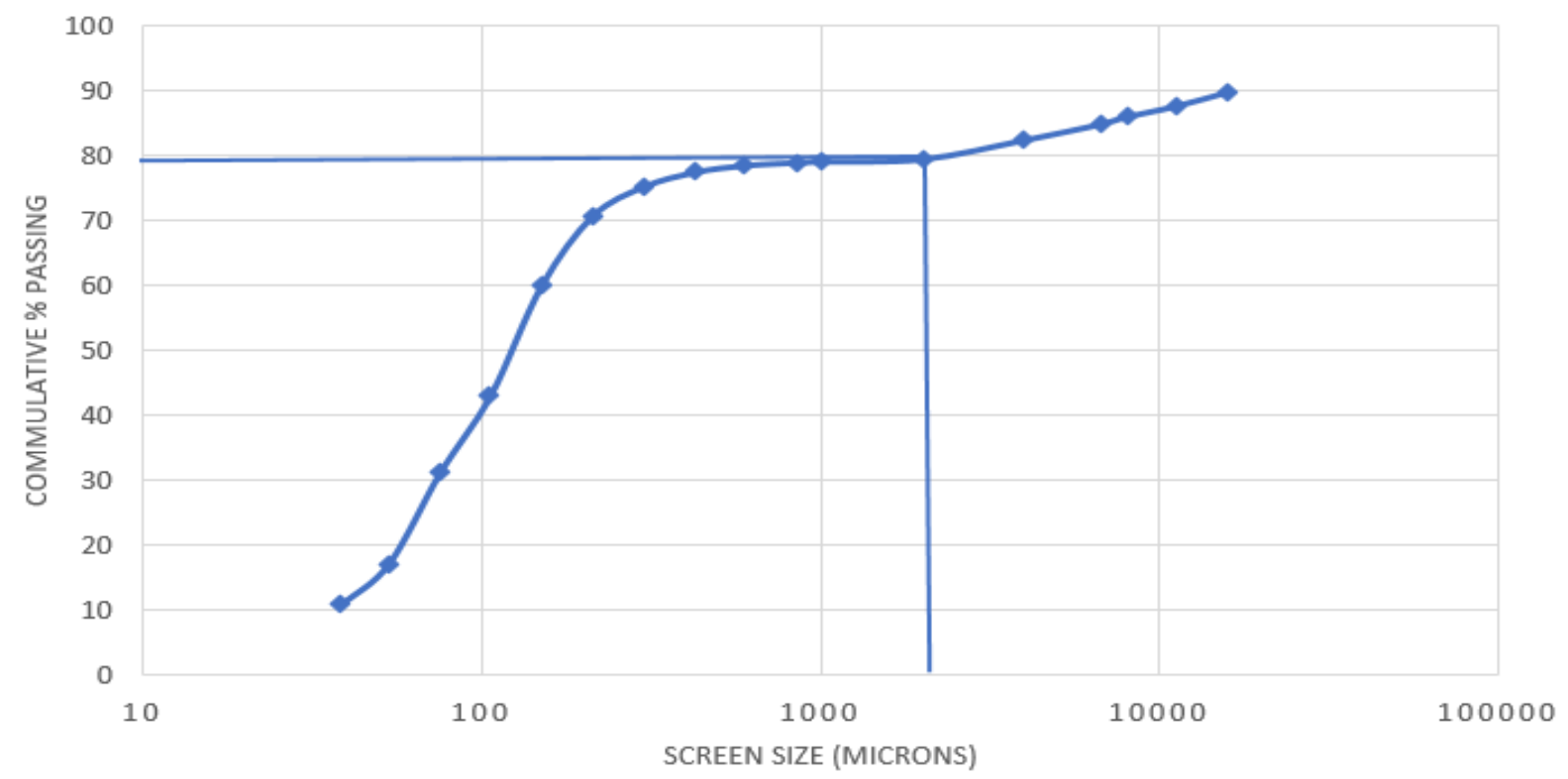

Fig 3: Particle size distribution of the custom mill tailings

The surface topography of the samples was analysed using SEM-EDs and the results are shown in Figure 4. The following phases were revealed 1- Quartz \& chalcopyrite , 2- arsenopyrite, 3- pyrite and Titanium oxide, 4 and 5- quartz and 6-Pyrite.

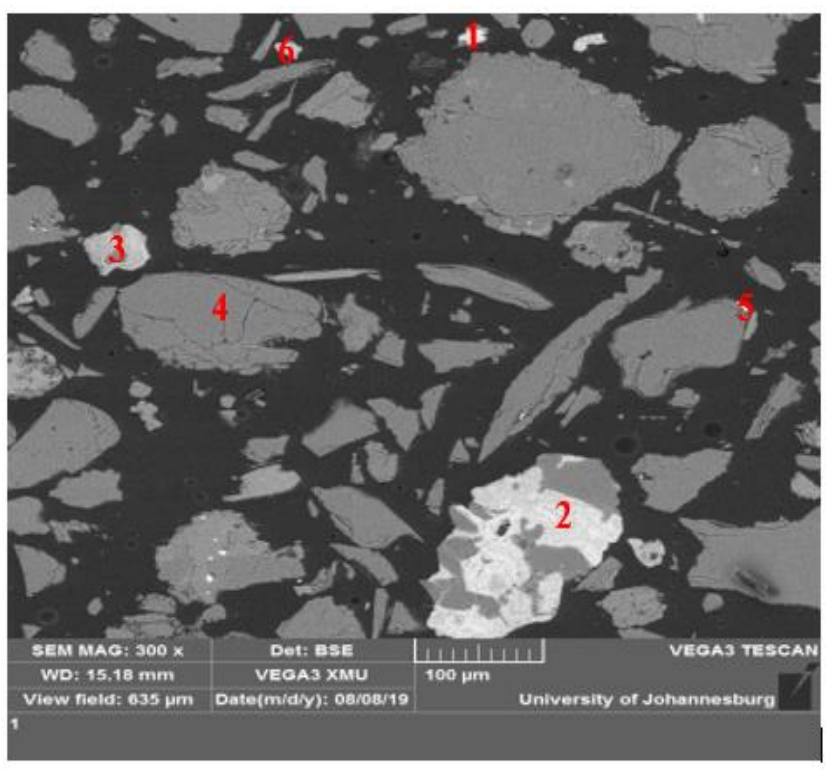

Fig 4: Micrograph of the custom mill tailings 
The dominant phase in the tailings was quartz. Minor sulphide phases were revealed but the quantity was very small ruling out the probability of the ore being refractory. Hence, gold and silver recoveries can be increased by liberation and leaching using the correct leaching conditions without any pre-treatment.

\subsection{Impact of leaching time and $\mathrm{NaCN}$ on gold recovery}

The impact of leaching time and $\mathrm{NaCN}$ concentration on leaching of gold tailings from a custom mill was assessed using the leaching conditions shown in Table 1 and analysed using Minitab software. The results are shown in Figure 5. Figure 5 illustrates that that Au recovery can be increased from 65 to $95 \%$ by increasing the leaching time from $4 \mathrm{hrs}$ to $8 \mathrm{hrs}$ and increasing the cyanide concentration from 400 to $800 \mathrm{~g} / \mathrm{t}$. However, recoveries above $85 \%$ can be obtained by leaching in $600 \mathrm{~g} / \mathrm{t}$ for $8 \mathrm{hrs}$.

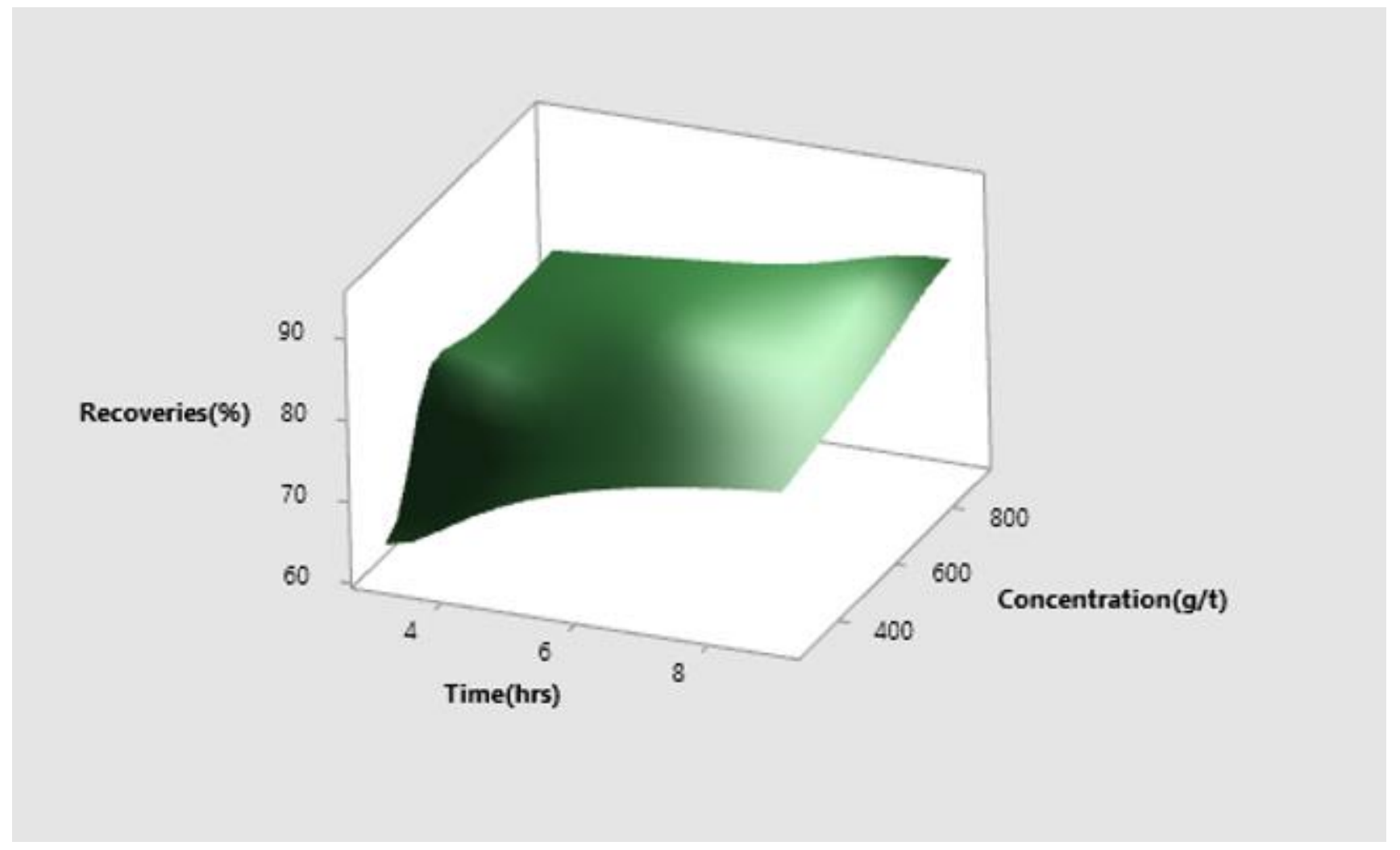

Fig 5: Impact of leaching time and $\mathrm{NaCN}$ concentration on gold recovery

The effect of leaching time and $\mathrm{NaCN}$ concentration was assessed by leaching the custom mill tailings under the conditions shown in Table 1 and the results are shown in Figure 6. The Silver recovery increased from 63 to $88 \%$ by increasing the leaching time from 4 to $8 \mathrm{hrs}$ and $\mathrm{NaCN}$ concentration from 400 to $800 \mathrm{~g} / \mathrm{t}$. 


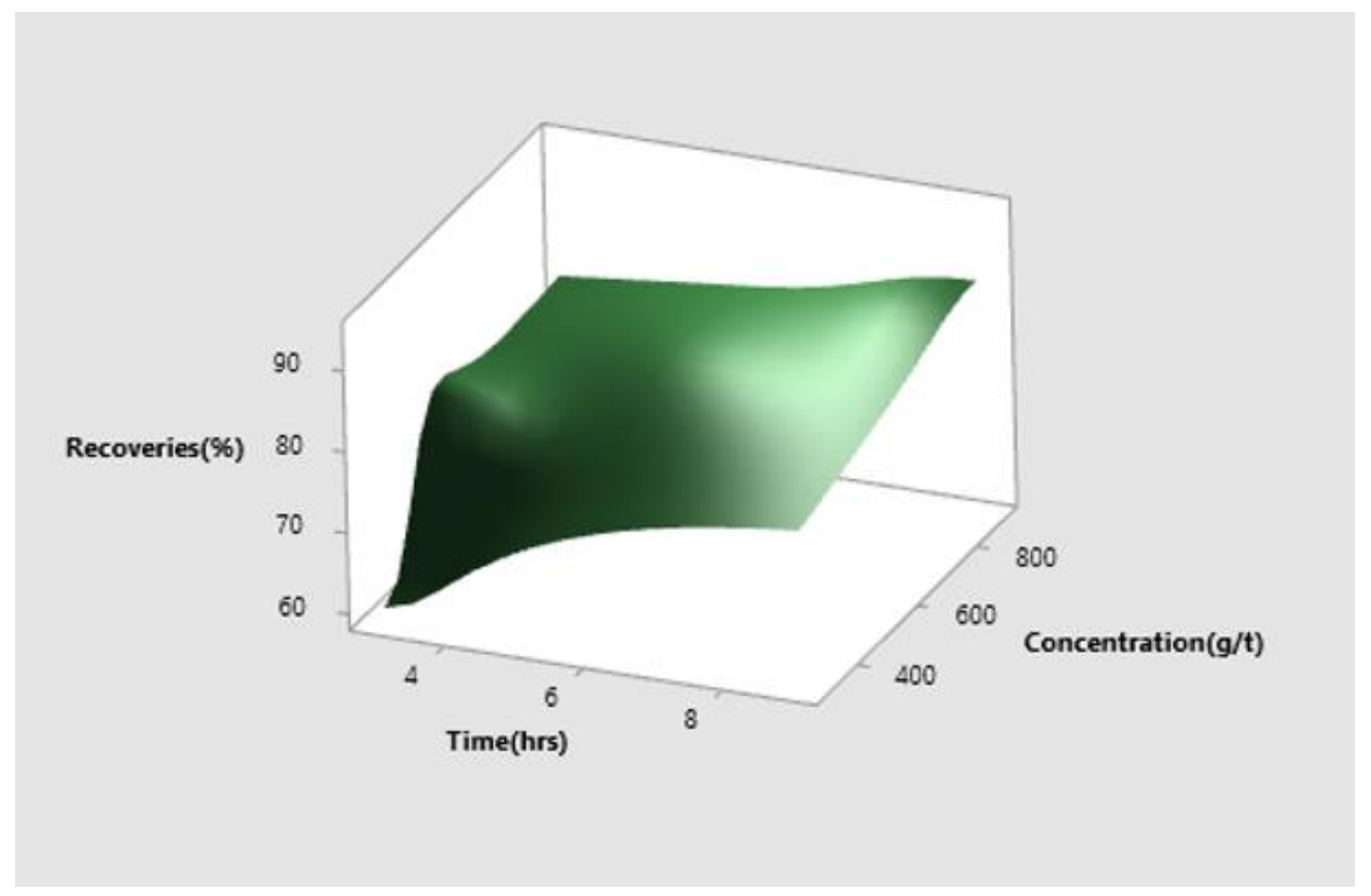

Fig 6: Impact of $\mathrm{NaCN}$ concentration and leaching time on silver recovery

\section{Conclusion}

The present study demonstrated that gold lost in the custom mill tailings can be recovered by cyanidation and the leaching process can be optimised using Minitab software. It has been proved that by reducing the PSD of the custom mill tailings to $80 \%$ passing $74 \mu \mathrm{m}$, controlling the leaching time and the sodium cyanide concentration, silver and gold recoveries can be increased to 88 and $95 \%$ respectively. Custom mill tailings from Shamva area contains 2.01g/t Au and $1.5 \mathrm{~g} / \mathrm{t} \mathrm{Ag}$ and it's a potential source of precious metals. It is a quartzite ore and there is no need for pre-treatment of the tailings. Minitab software has proved to a useful tool in optimisation of the leaching conditions and in assessing the interactive effects of the leaching parameters.

\section{Acknowledgements}

Acknowledgement is given to a Custom mill in Shamva, Zimbabwe for the sample provided and the University of Johannesburg for laboratory facilities.

\section{References}

[1] G. Damonte, "The "Blind" State: Government Quest for Formalization and Conflict with Small-Scale Miners in the Peruvian Amazon," Antipode, vol. 48, no. 4, pp. 956-976., 2016.

[2] A. Knoblauch, A. Farnham, J. Ouoba, J. Zanetti, S. Müller, V. Jean-Richard, J. Utzinger, B. Wehrli, F. Brugger, S. Diagbouga and M. Winkler, "Potential health effects of cyanide use in artisanal and small-scale gold mining in Burkina Faso," Journal of Cleaner Production, vol. 252, p. 119689, 2020.

[3] P. Appel and L. Na-Oy, "The borax method of gold extraction for small-scale miners," Journal of Health and Pollution, vol. 2, no. 3, pp. 5-10, 2012. 
[4] B. Stoffersen, P. Appel, L. Na-Oy, A. Sekamane, I. Ruiz and R. Køster-Rasmussen, "Introduction of mercury-free gold extraction to small-scale miners in the Cabo Delgado province in Mozambique," Journal of Health and Pollution, vol. 8, no. 19, pp. 1-5, 2018.

[5] E. Caballero, "Traditional small scale miners: Women miners of the Philippines," Women Miners in Developing Countries, pp. 145-162, 2017.

[6] J. Mbayo, H. Simonsen and S. Ndlovu, "Improving the gold leaching process of refractory ores using the Jetleach reactor," Minerals Engineering,, vol. 134, pp. 300-308, 2019.

[7] M. Mubarok, R. Winarko, S. Chaerun, I. Rizki and Z. Ichlas, "Improving gold recovery from refractory gold ores through biooxidation using iron-sulfur-oxidizing/sulfur-oxidizing mixotrophic bacteria," Hydrometallurgy, vol. 168, pp. 69-75, 2017.

[8] R. Esmkhani, B. Ghobadi and A. A. \&. S. Rezadust, "The Effect of Increasing Capacity on Gold Recovery and Optimization of Cyanidation Parameters in Aghdarreh Gold Ore Plant," Australian Journal of Basic and Applied Sciences, vol. 3, no. 7, pp. 702-208, 2013. 